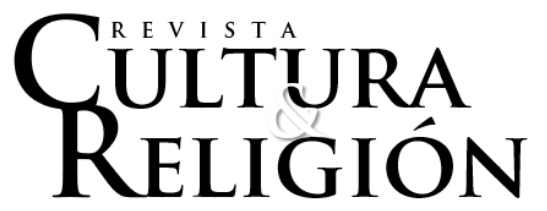

Vol. XIII, N 2 (2019) pp. 103-121

Recibido: 10 de mayo, 2019

Aceptado: 9 de noviembre, 2019

\title{
LA SANTA MUERTE EN LA CIUDAD DE MÉXICO: DEVOCIÓN, VIDA COTIDIANA Y ESPACIO PÚBLICO ${ }^{1}$
}

\author{
La Santa Muerte in Mexico city: devotion, everyday life and public space
}

\author{
por \\ Roberto Garcés Marrero* \\ Universidad Iberoamericana, Ciudad de México \\ rgmar18777@hotmail.com
}

\begin{abstract}
Resumen
La Santa Muerte es una devoción mexicana muy conocida, en México y fuera de él. En este trabajo se trata de, a través del trabajo etnográfico, explicar qué significa la Santa Muerte para sus devotos en su vida cotidiana y en su habitar una de las mayores ciudades del mundo. Se hace énfasis en la caracterización que hacen los fieles de la Santa y en los prejuicios que enfrentan, así como al derrumbe de altares públicos que han ocurrido luego de la declaración de guerra al narco a finales de 2006. En la Ciudad de México los altares públicos que aún perduran y en general el culto abierto se da en las colonias más vulnerables de la zona urbana. También se puede sostener la hipótesis de que la Santa Muerte es una devoción que llega a la ciudad desde los estados circundantes a mediados del siglo pasado, momento en que hubo un boom demográfico en gran medida causado por la migración.
\end{abstract}

Palabras claves: Santa Muerte, Ciudad de México, espacio urbano

\begin{abstract}
La Santa Muerte is a very known Mexican devotion, in Mexico and beyond. In this work it is about, through ethnographic work, explain what Santa Muerte means for its devotees in their daily life and in their living in one of the biggest cities in the world. Emphasis is placed on the characterization made by the faithful of the Saint and on the prejudices they face, as well as the collapse of public altars that occurred after the declaration of war on narco at the end of 2006. In Mexico City the altars public that still endure and in general open worship occurs in the most vulnerable neighborhoods of the urban area. It can also be hypothesized

\footnotetext{
${ }^{1}$ Este trabajo fue elaborado en el marco de la Beca Ibero y la Beca CONACYT

* Doctorando en Antropología Social, Universidad Iberoamericana, Ciudad de México. (Beca Ibero/ Beca CONACYT). Doctor en Ciencias Filosóficas (UCLV, 2014). https://orcid.org/0000-0003-4925-1743
}

Revista Cultura \& Religión Vol. XIII, 2019 № 2 (julio-diciembre)

Cómo citar este artículo: Garcés, R. (2019). "La Santa Muerte En La Ciudad De México: Devoción, Vida Cotidiana Y Espacio Público ”. Revista Cultura \& Religión.13(2). pp. 103-121. 
that Santa Muerte is a devotion that reaches the city from the surrounding states in the middle of the last century, when there was a demographic boom largely caused by migration.

Keywords: Santa Muerte, Mexico City, urban space

\section{Introducción}

México es un país caracterizado por la diversidad; su capital, la Ciudad de México, es una de las megalópolis más grandes del mundo, cuyos límites difuminados, ya conurbanos con el Estado de México, se extienden por un área de casi ocho mil kilómetros cuadrados, haciendo que la Zona Metropolitana abarque la mayor parte de la región geográfica de la cuenca de México. Semejante monstruo urbano es en realidad un caleidoscopio de ciudades, vidas, cotidianidades, cada una de las cuales implica una diferente manera de habitar ese espacio, a veces en mundos aislados que coexisten sin interacción apenas (Saraví, 2008) y donde lo mestizo, como lo llama Huffschmid (2012) es el marco que todo lo abarca.

Esta es la ciudad que engloba al cerro de Tepeyac, donde según la tradición el 12 de diciembre de 1531 se le apareció la Virgen de Guadalupe a Juan Diego, pidiéndole que le comunicara al obispo que le construyera un templo en ese lugar. Ese relato, cuestionado desde el siglo XVIII, resulta interesante porque la Virgen se aparece precisamente al indígena recién evangelizado. A lo largo de los siglos siguientes esta Virgen mestiza acercaría más al cristianismo a grandes masas indígenas, quienes en su rostro oscuro encontrarían rasgos familiares en la que en definitiva seguía siendo la Madre del Dios del conquistador. De la Ciudad de México se diseminó al resto de la nación mexicana la veneración a esta advocación mariana. No es raro que, en casi todo el espacio urbano capitalino, en parques, esquinas, fachadas de edificios e incluso aceras, se encuentren altares más o menos notables de la Emperatriz de las Américas, los cuales son atendidos asiduamente.

Sin embargo, hace cerca de dos décadas ciertas áreas de la ciudad comenzaron a mostrar otros altares a una figura femenina, ataviada como la Virgen: la Santa Muerte, también llamada por los devotos la Flaquita, la Niña Blanca, la Santa, la Patrona, la Señora o la Madrina, algunos de estos nombres serán utilizados a lo largo del presente texto de manera aleatoria al mencionarla. Poco se sabe de su origen: creyentes e investigadores apuntan hacia Veracruz, Guanajuato, Querétaro, Zacatecas, Hidalgo, Michoacán, Oaxaca, Chiapas (Perdigón, 2017; Chesnut, 2013; Gil Olmos, 2012; Gaytán, 2008). Puede ser que la devoción no sea autóctona de la Ciudad de México, sino que vino con la migración de trabajadores de bajos recursos de otros estados y comienza a hacerse visible a medida que conquista más espacios en la ciudad. Algunos datos ofrecidos por los colaboradores de esta investigación apuntan hacia ese origen. Los devotos entrevistados que cuentan con tradición familiar en el culto señalan como pioneras a sus abuelas o madres, siempre mujeres, lo cual, utilizando el método genealógico, señalaría como posible fecha de comienzo del culto en la

Revista Cultura \& Religión Vol. XIII, 2019 Nº 2 (julio-diciembre)

Cómo citar este artículo: Garcés, R. (2019). "La Santa Muerte En La Ciudad De México: Devoción, Vida Cotidiana Y Espacio Público ”. Revista Cultura \& Religión.13(2). pp. 103-121. 
Ciudad las décadas de los cuarenta o cincuenta del siglo pasado, momento en el que la capital comienza un boom demográfico: de 1950 a 1970 la población citadina se triplicó con un crecimiento anual del cinco por ciento, es decir una duplicación cada diez años (Gracia Sain, 2004), pasando de tres millones a poco más de nueve millones, siendo la migración una de las causas principales, representando entre el 25 y el $35 \%$ de ese crecimiento (Cruz Rodríguez, 2000). El tope de la densificación de la zona residencial del Centro Histórico de la Ciudad de México a partir de la migración campo- ciudad ocurrió en los cincuenta (Díaz, 2016). Al respecto Gracia Sain plantea:

Desde los años cuarenta hasta aproximadamente la década de los setenta, la dinámica del crecimiento urbano en México estuvo sumamente influida por el modelo económico de sustitución de importaciones, basado en el uso intensivo de mano de obra en actividades industriales, que fortaleció un asentamiento poblacional muy concentrado en la Ciudad de México. (2004, p. 110)

En esos años la ciudad estaba constituida por doce cuarteles que hoy conforman las alcaldías de Cuauhtémoc, Venustiano Carranza, Benito Juárez y Miguel Hidalgo, así que la colonia en la que se realizó el presente estudio estaba enmarcada dentro de los límites citadinos, en un momento donde se vivía un proceso de urbanización acelerada. Luego de los ochenta con la desindustrialización de la ciudad, el desplazamiento de la población del centro a la periferia y el vertiginoso crecimiento periférico que conllevaría a la conurbación con municipios cercanos, el aumento de población sería precisamente en el Estado de México, en particular Tultitlán y Ecatepec, dos de los lugares reconocidos también por el culto a la Santa Muerte. Por esto, si bien los altares públicos de la Virgen de Guadalupe se pueden encontrar en cualquier lugar de la Zona Metropolitana, la Santa Muerte se ubica como devoción abierta y visible dentro del espacio urbano en las colonias más vulnerables de la Ciudad de México o en el Estado de México y protagonizado por personas de clase media a baja, a diferencia de los casos reportados por Argyriadis (2017) en Veracruz, por ejemplo, lo que patentiza la necesidad de analizar el culto de manera particular en cada región.

La Virgen de Guadalupe se extendió de la Ciudad de México al resto del país, la Santa Muerte va haciendo el recorrido contrario. Sus altares significan una manera de apropiación del espacio público capitalino por parte de cierta sección de la población, vulnerable, discriminada e invisibilizada. El presente trabajo se encamina a realizar un análisis de la devoción de la Santa Muerte en dos dimensiones: qué creen los devotos de la Santa Muerte y cuál es el papel de esta devoción en la vida cotidiana de sus creyentes. A partir de ahí se pueden comprender las diferentes reconfiguraciones de la Ciudad y sus maneras de habitarla, tomando desde el punto de vista teórico la "dwelling perspective" de Tim Ingold y las ideas de Henri Lefebvre sobre ciudad y espacio. Desde el eje del análisis religioso se intenta articular la perspectiva de "lived religion" de Ammerman (2014) con la de religión popular. La base empírica de este artículo es el trabajo de campo realizado en un oratorio a la Santa Muerte de la Zona Centro, alcaldía Venustiano Carranza, realizado de diciembre de 2018 a junio de 2019 como parte del proyecto de investigación doctoral del autor, aún en curso.

Revista Cultura \& Religión Vol. XIII, 2019 Nº 2 (julio-diciembre)

Cómo citar este artículo: Garcés, R. (2019). "La Santa Muerte En La Ciudad De México: Devoción, Vida Cotidiana Y Espacio Público ”. Revista Cultura \& Religión.13(2). pp. 103-121. 
Hasta el momento se han registrado muy pocas investigaciones que tomen lo religioso como punto de partida para analizar el uso del espacio urbano y viceversa, en una relación dialéctica y enriquecedora (Flores, 2016). Está documentado que la mayoría de las investigaciones sobre la Santa Muerte en la Ciudad de México han sido llevadas a cabo en el altar de la calle Alfarería en el barrio de Tepito (Yllescas, 2017), por eso este estudio trata de explorar otras áreas que brinden nuevas pistas sobre este culto.

Este tipo de trabajo podría ser denominado etnografía en la incertidumbre, debido a que relativiza la archiconocida relación de poder del investigador sobre sus colaboradores. El antropólogo está inmerso en zonas de altos niveles de violencia. El propio proceso investigativo puede resultar vulnerable, en tanto que existe la posibilidad de que los colaboradores corten la relación con el investigador sin previo aviso y sin motivos claros, como ocurrió con algunos de los que aquí se mencionan, a pesar del tiempo y esfuerzo invertido en la construcción de rapport y de vías de comunicación. Por otra parte, en ocasiones se prefirió por razones éticas y de conveniencia para el resultado de la investigación no profundizar en ciertos detalles: por ejemplo, los entrevistados parecían muy dispuestos a contar sobre la Santa Muerte, pero eran muy reticentes a la hora de hablar sobre sus vidas y ocupaciones, lo cual significó que la información sociodemográfica tuvo que ser reconstruida, de manera incompleta, a partir de comentarios aislados y de la observación.

\section{Habitar la ciudad, conviviendo con la Muerte}

El paisaje urbano es también religioso y viceversa; ha sido construido por y de vidas pasadas, es decir con las diversas maneras de vivirlo a lo largo del tiempo: "the landscape is constituted as an enduring record of - and testimony to - the lives and works of past generations who have dwelt within it, and in so doing, have left there something of themselves." (Ingold, 1993, p. 152) En este punto habría una coincidencia entre la línea de pensamiento de Ingold y de Lefebvre:

En el tiempo y en el espacio se suceden disoluciones de estructuras y reestructuraciones, siempre traducidas sobre el terreno, inscritas en lo práctico- sensible, escritas en el texto urbano, pero derivando de una procedencia distinta: de la historia, del devenir. Y ello no de lo suprasensible, sino de otro nivel. Las ciudades fueron marcadas por actos y agentes locales, pero también por las relaciones impersonales de producción y propiedad, y por consiguiente de clases y luchas de clases; y, subsiguientemente, por las ideologías (religiosas, filosóficas, es decir, éticas y estéticas, jurídicas, etc.). La proyección de lo global sobre el terreno y sobre el plano específico de la ciudad solo se efectuó a través de mediaciones. La ciudad, mediación a su vez, fue el lugar, el producto de las mediaciones, el terreno de sus actividades, el objeto y el objetivo de sus proposiciones. (Lefebvre, 1973, p. 73)

Existe una manera religiosa de habitar ese lugar urbano en constante construcción, la cual se expresa en la consagración de espacios y actividades -presentes y pasadas- realizadas en los mismos, que manifiestan la relación que establecen los habitantes entre ellos y con lo sagrado, que no siempre supone una dicotomización con lo profano. Este habitar también

Revista Cultura \& Religión Vol. XIII, 2019 Nº 2 (julio-diciembre)

Cómo citar este artículo: Garcés, R. (2019). "La Santa Muerte En La Ciudad De México: Devoción, Vida Cotidiana Y Espacio Público ”. Revista Cultura \& Religión.13(2). pp. 103-121. 
implica una pugna de fuerzas y poderes que se contraponen y enfrentan (Ingold, 2005), como se puede apreciar en el ejemplo de los altares públicos a la Virgen de Guadalupe y a la Santa Muerte en la Ciudad de México, donde se pone en manifiesto lo que Lefebvre (1973) denomina dimensión paradigmática de la ciudad. ¿Dónde están unos y otros? ¿Por qué? ¿Qué relaciones políticas, religiosas y de clase exponen? ¿Cómo se comprende su manera de habitar la ciudad desde allí? La respuesta de todas estas preguntas se encuentra en la vida cotidiana de estas personas, en este caso, habitantes de zonas céntricas de la ciudad, desde el punto de vista geográfico, pero marginales por sus condiciones sociales.

Desde la precariedad que habitan estas personas se construyen constantemente modos cotidianos de habitar la ciudad, su ciudad, en la cual expresan su manera de entender el mundo. Ingold (2005) hace énfasis de que los habitantes del mundo o determinado paisaje no solo son humanos. Aunque él se refiere a los animales básicamente, podríamos agregar que para los humanos también hay ciertos no humanos, sobrenaturales si se quiere, que habitan tanto como ellos sus espacios, compartiendo su vida del día a día, sus inquietudes, alegrías y tristezas. Tal es el caso de la Santa Muerte que, aunque suene paradójico puede decirse que convive con sus creyentes, compartiendo sus, a veces escasos, alimentos, casa, bebida, como un miembro más de la familia (de la Fuente, 2015). La negación de la expresión pública de su devoción en la Flaquita, como la llaman con afecto, se traduce en una negación a ellos mismos y a su manera de vivir. La ciudad, respecto a la devoción a la Niña Blanca, también "es lugar de confrontaciones y de relaciones (conflictivas) entre deseo y necesidad, entre satisfacción e insatisfacción” (Lefebvre, 1973, p. 76).

En este trabajo se parte de la articulación entre las perspectivas de religión popular y lived religion. Es importante destacar que se asume la crítica de Parker (1993) a entender la religión popular como subalterna y desviada de la ortodoxia. Más bien se toma como una alternativa conceptual y metodológica a la perspectiva institucional del estudio de las religiones tanto como a su concepción puramente individual. La religión popular entonces puede explicar los procesos de asimilación y rechazo a la modernidad por parte de creencias caracterizadas por el sincretismo (De la Torre, 2012), donde los creyentes no se circunscriben a la ortodoxia dictada desde una institución, sino que anclándose en esta también exploran, combinan y recrean nuevas maneras de vivir su espiritualidad. Es decir, no se abandona el estudio de instituciones religiosas de largo trayecto, ni la asunción personal de una fe, sino que se mantiene la mirada en estos intersticios, en los "espacios umbral" (De la Torre, 2012, p. 509), entendiendo así la manera en que se viven estas nuevas espiritualidades, que adquieren de tradiciones anteriores su legitimidad y reinterpretan sus prácticas. La religión popular se convierte en el lugar estratégico para "estudiar el reacomodo constante, de ida y vuelta entre lo nuevo y lo tradicional, saliendo de las instituciones, pero mirando hacia su recomposición, dando seguimiento a las movilidades, pero sin perder de vista los enraizamientos en la tradición." (De la Torre, 2012, p. 518) Cabe aclarar que actualmente la religión popular no es privativa de clases bajas, sino que ha sido apropiada y recreada por

Revista Cultura \& Religión Vol. XIII, 2019 N² 2 (julio-diciembre)

Cómo citar este artículo: Garcés, R. (2019). "La Santa Muerte En La Ciudad De México: Devoción, Vida Cotidiana Y Espacio Público ”. Revista Cultura \& Religión.13(2). pp. 103-121. 
clases más altas en un proceso de gentrificación descrito por Possamai (2015), así que no puede ser analizada en clave clasista exlusiva.

Por su parte la perspectiva de Ammerman de "lived religion" resulta provechosa para este estudio en tanto que hace un énfasis particular en la dimensión personal y cotidiana de la fe, en cómo, cuándo y dónde el creyente materializa e incorpora su espiritualidad a su día a día, de manera individualizada. Según esta autora: "Looking for lived religion does mean that we look for the material, embodied aspects of religion as they occur in everyday life, in addition to listening for how people explain themselves. (...) (Ammerman, 2014, pp. 190191)" Se combinarán ambas perspectivas en un intento de abarcar tanto la vivencia cotidiana de esta devoción como su aspecto más comunitario para tratar de alcanzar su dimensión urbana.

En el caso del culto a la Santa Muerte, la vivencia cotidiana de la relación con la Niña Blanca es fundamental. Esta es verdaderamente incorporada al cuerpo, al espacio íntimo, familiar y también a lo urbano en sus diferentes dimensiones, rehuyendo los diferentes intentos de institucionalizarla y las fuertes luchas de poderes que existen en torno a ella. Se podría afirmar, a pesar del aparente oxímoron, que nos dirigimos a explicar cómo es la (con)vivencia de la Muerte en este culto mexicano y cómo se ha manifestado en la manera de habitar la ciudad.

\section{Zona Centro y el oratorio de la Señora Blanca. El rosario a la Santa Muerte}

El oratorio de la Señora Blanca se enmarca en una de las zonas marginales, no periféricas de la ciudad, en la parte que Gracia Sain (2004) categoriza como centro histórico, donde pueden convivir diversos estratos socioeconómicos con una alta densidad tanto de viviendas como de habitantes. Desde las fachadas desconchadas de los edificios de no más de dos o tres plantas en su mayoría, hasta la suciedad extrema de la vía pública, con ocasionales desbordamientos de aguas negras en las calles menos importantes, denota el nivel de precariedad de esa parte de la Zona Centro, considerada por parte de sus habitantes y de la ciudad en general, una de las más inseguras por sus niveles de violencia. El declive de la zona del Centro Histórico, en general

[...] es el resultado de decisiones sobre la inversión pública y privada, que dan lugar a un círculo vicioso de pérdida de valor, desinversión y deterioro por falta de mantenimiento, que libera capital para ser invertido en otros lugares. En segundo lugar, están los propios procesos de filtrado residencial hacia grupos progresivamente menos pudientes en el Centro Histórico de la Ciudad de México. Además, está la cuestión de la terciarización del Centro Histórico de la Ciudad de México que, progresivamente, en la segunda mitad del siglo XX, se irá convirtiendo en el centro comercial de las clases populares. La competencia del comercio, con capacidad de pagar rentas más altas por una ubicación central que la residencia popular, será un factor determinante en el despoblamiento. (Díaz, 2016, p. 132)

\section{Revista Cultura \& Religión Vol. XIII, 2019 № 2 (julio-diciembre)}

Cómo citar este artículo: Garcés, R. (2019). "La Santa Muerte En La Ciudad De México: Devoción, Vida Cotidiana Y Espacio Público ”. Revista Cultura \& Religión.13(2). pp. 103-121. 
El espacio dejado por el desplazamiento de la clase media iba siendo ocupado por el éxodo rural, además de que el fraccionamiento de viviendas unifamiliares para convertirse en vecindades desvalorizaba la zona. El punto crítico de esta decadencia fue el sismo de 1985, el cual significó el fin de edificios que sufrían de una crónica falta de mantenimiento y de sobreuso, a lo que se sumó la invasión de inmuebles sobre todo por parte de grupos indígenas (Díaz, 2016). Esta es, a grandes rasgos, la historia de esta zona.

En el Oratorio de la Señora Blanca, sito en Ferrocarril de Cintura 38 e/ San Antonio y Alarcón, Zona Centro, alcaldía Venustiano Carranza, cada primero de mes se celebra un rosario a la Santa. Muerte a las $12 \mathrm{~m}$ y a las $6 \mathrm{pm}$. Las paredes del lugar, que funge también como tienda de imaginería de la devoción de la Santa, están llenas de figuras de esqueletos encapuchados y de largas vestiduras talares de diferentes colores, con búhos a sus pies y ofrendas en las manos. La iconografía con la que se representa a la Santa es la que la tradición europea atribuye a la muerte: un esqueleto vestido con la túnica negra y talar, la guadaña, a veces la balanza, el búho y sostiene una esfera simbolizando que en sus manos está el mundo. Generalmente se muestra su rostro descarnado, pero a veces se le cubre la cara como con un velo o se representa como un ángel muy femenino. Dicen sus devotos que no tiene corona porque es un ser espiritual muy humilde, por eso sus seguidores deben evitar la soberbia y ser como ella, sin embargo, se ha podido observar muchas imágenes coronadas, lo cual comprueba la vieja idea feuerbachiana de que la devoción puede ser proyectiva. En algunos casos se recrean imágenes muy conocidas, como la de la Pietá, donde la Virgen María es sustituida por una Santa Muerte que sostiene en sus brazos el cuerpo exánime de Cristo, luego de que fuese bajado de la cruz porque "fue ella quien lo llevó ante el Padre". Una de las frases en sus oraciones dice: Jesucristo vencedor, Tú que en la cruz fuiste vencido..." retomando esta idea que encomia la fuerza de la Muerte, al punto que el Hijo de Dios, Dios mismo, tuvo que morir para cumplir su misión en la tierra.

En el oratorio siempre hay flores y veladoras ante la imagen principal, llamada Esperanza, a la cual le cambian el vestuario mensualmente. Acuden a los rezos no más de quince personas. Muchos van vestidos de negro. La hermana Rosa dirige las oraciones, tapa sus hombros con una estola negra y un pañuelo negro cubre su cabeza. Al principio enciende un sahumerio y lo pone en la entrada, para espantar malas influencias. El rosario se parece mucho a los católico-romanos. Se repiten ave Marías y Padre Nuestros, intercalando invocaciones a la Santa Muerte. Se le ruega por protección, que "cubra a todos sus devotos con su manto oscuro". Mientras se reza, un señor mayor va ungiendo a cada uno de los presentes, en tres momentos distintos de la celebración, con perfume, aceite y licor. Los unta en la frente, en la nuca y en las manos. Se repite varias veces un fragmento de la oración: "ojos tengan y no me vean, manos tengan y no me toquen, pies tengan y no me alcancen, armas tengan y no disparen..." El constante clamor por protección hace evidente el profundo sentimiento de inseguridad que vivencian los creyentes; como señala Huffschmid: "La certidumbre de la muerte se invoca como protectora ante las incertidumbres de la vida..."

Revista Cultura \& Religión Vol. XIII, 2019 № 2 (julio-diciembre)

Cómo citar este artículo: Garcés, R. (2019). "La Santa Muerte En La Ciudad De México: Devoción, Vida Cotidiana Y Espacio Público ”. Revista Cultura \& Religión.13(2). pp. 103-121. 
(2012, p. 106) Es notorio el marcado sincretismo de esta práctica, donde se toma como base elementos del catolicismo popular ${ }^{2}$ para erigir la liturgia, combinándola con prácticas shamánicas. Como plantea Renée de la Torre sobre la religión popular en general: "más que ser una espiritualidad paralela es transversal a la institución.” (De la Torre, 2012, p. 511)

Se hace un minuto de silencio para que los asistentes presenten sus peticiones a la imagen de la Santa (es la imagen mayor del oratorio, la llamada Esperanza), luego se le encienden veladoras y se le ruega que ilumine a todos los presentes. Se les pide a los creyentes que se den la paz unos a otros y después que eleven las manos hacia la imagen, solicitando su amparo una vez más. Una de las oraciones dice: "dame tus ojos para que pueda ver, tus manos para que pueda hacer" y se va pidiendo a la Santa que le dé cada parte de su cuerpo a los creyentes, haciendo así un ritual impresionante de identificación corporal completa de los devotos con la Muerte, una verdadera invocación para que la Santa encarne en sus cuerpos. El uso del cuerpo en el culto, sobre todo a través de los brazos extendidos, parece ser generalizado (Yllescas, 2017).

En las lecturas que hace la hermana Rosa de un grupo de papeles dispersos se escuchan reflexiones sobre el ser humano y su ineluctable devenir hacia la Muerte, quien, según se dice ama a todos y acompaña a todos: "de nada sirve tratar de evitarla, ella sigue todos nuestros pasos." Como describe Huffschmid de su experiencia en otro oratorio, pero aplicable a este: "No hay morbo, acaso un dejo de melancolía existencialista, y una necesidad palpable y desbordada de entrega espiritual." (2012, p. 104) Se repite constantemente que no se debe usar la fuerza de la Santa para hacer el mal o hacer hechicería, insistiendo en que se los cobrará después. Concluyendo se dan vivas a la Muerte, le cantan "a la bin a la bao, a la bim bom bao, la Muerte, la Muerte, ra ra ra eh". Se grita una y otra vez: "se oye, se siente, la Muerte está presente". Al final se comparten unos refrescos que trajeron los devotos. El rosario y el acto de darse la paz denota una clara influencia de la devoción católica. De manera general, es muy similar a otras ceremonias de esta especie descritas por investigadores como Perrée (2014) y Argyriadis (2017), exceptuando que no son seguidas por una parte festiva como señala la segunda antropóloga en el caso jarocho.

En conversaciones anteriores con la hermana Rosa me explica que en la devoción a la Santa Muerte -a quien llama "la Señora"- no hay proceso de iniciación, la entrada al culto es espontánea. Generalmente ocurre por momentos difíciles de la vida en la que se le pide intersección a la Santa. A partir de cumpla la petición, los creyentes se consagran a su culto. La hna. Rosa comenzó el culto a los 13 años. En la actualidad lleva 30 años venerando a la

\footnotetext{
${ }^{2}$ Se toma la definición de catolicismo popular dada por Parker (1993) para quien esta espiritualidad se expresa en las peregrinaciones a santuarios, generalmente dedicados a la Virgen o a santos populares; el uso de ciertos sacramentos como rito de pasaje (bautismo, comunión, matrimonio, velorio); la celebración de festividades propias del calendario litúrgico como la Navidad o Semana Santa; la no asistencia regular a la práctica dominical y el desarrollo de la devoción cotidiana de manera independiente a lo prescrito por la Iglesia. (pp. 167-169)
}

Revista Cultura \& Religión Vol. XIII, 2019 Nº 2 (julio-diciembre)

Cómo citar este artículo: Garcés, R. (2019). "La Santa Muerte En La Ciudad De México: Devoción, Vida Cotidiana Y Espacio Público ”. Revista Cultura \& Religión.13(2). pp. 103-121. 
Señora, como la llama. A su mamá, la Sra. Blanca, "le hicieron un daño" y cayó en cama. La doméstica de la casa (originaria de Oaxaca) le habló de la Santa. Según cuenta, al principio se resistieron, pero al final aceptaron la ayuda. La muchacha que las ayudaba en las labores del hogar trajo a su mamá desde Oaxaca, pues era la que sabía qué hacer en esos casos. Le hizo limpias a la Sra. Blanca, le pidió a Rosa que comprara una imagen de la Santa y le hiciera una novena. Rosa hizo la promesa de que si su mamá se levantaba ella continuaría su culto. La madre se recuperó y la hermana Rosa se dedicó al culto desde entonces, incluso en el período que estuvo en los EE. UU. Allá tuvo varios problemas por la cantidad de gente que entraba a su casa para las limpias. Incluso tuvo que cambiar de casa y la policía le hizo varios registros. Al final fue deportada, por carecer de documentos migratorios y continúa con su devoción en el oratorio de su mamá. Como vemos, tanto la sugerencia de comenzar la devoción, como los rituales de esta fueron por parte de una inmigrante oaxaqueña que laboraba como doméstica, esta es una posible vía de llegada del culto a la Santa en la Ciudad de México, lo cual es ratificado por otros creyentes, como veremos luego.

Para Rosa, la señora Blanca fue una de las iniciadoras del culto a la Sta. Muerte en la Zona Centro y es uno de los nombres fundamentales de la devoción en la zona, junto a la Sra. Queta, la dueña del oratorio más famoso y al Padre David Romo Guillén, fundador de la Iglesia Católica Tradicional y muy conocido por los múltiples escándalos que ha protagonizado. Fue la Sra. Blanca, dice su hija, la que introdujo la tradición de nombrar las imágenes propias y de vestirlas. Se queja de que su mamá nunca ha querido reconocimiento y se resiste a hablar sobre su devoción. En la bibliografía consultada solo se le menciona por dos investigadores (Perdigón, 2017; Hernández, 2017): en el segundo caso se le dedica menos de un párrafo.

Rosa explica que su mamá incluso la cuestionó por dejarse entrevistar para esta investigación. Hasta ahora, a pesar de que haya estado en varias ocasiones en el oratorio, solo he visto a la Sra. Blanca de lejos y me saluda a distancia. Esto, además de rasgos personales, también se debe a la excesiva etnologización a la que han sido sometidos por parte de antropólogos de manera recurrente, pero sobre todo a la búsqueda agresiva de información protagonizada por otros profesionales, como periodistas, quienes tras la búsqueda del sensacionalismo a toda costa frecuentemente dejan resentimientos y desconfianza.

Según Katia Perdigón, este oratorio comienza el 5 de febrero de 2005, con el nombre de oratorio de Santa Esperanza, en honor a la imagen mayor venerada en este. Esta imagen, cuenta Perdigón, fue sacada a la calle del cercano local de la Iglesia Católica Tradicional, por el padre Romo Guillén, luego de que la Secretaría de Gobernación le retirara el permiso y traída aquí por la Sra. Blanca, donde es venerada desde entonces (Perdigón, 2017). Resulta curioso que en las varias entrevistas sostenida con su hija Rosa nunca haya mencionado esto, aunque ella misma fue la que me recomendó la lectura del libro de la antropóloga. Lamentablemente no se pudo contrastar el dato luego, debido a la pérdida inesperada de la

Revista Cultura \& Religión Vol. XIII, 2019 № 2 (julio-diciembre)

Cómo citar este artículo: Garcés, R. (2019). "La Santa Muerte En La Ciudad De México: Devoción, Vida Cotidiana Y Espacio Público ”. Revista Cultura \& Religión.13(2). pp. 103-121. 
relación. Solo se notó cierta reticencia a hablar sobre la cercana Iglesia Católica Tradicional. Como señala Argyriadis: "La devoción a la Santa Muerte refuerza un sentimiento comunitario entre los devotos, pero consecuentemente es sujeta a intensas luchas de poder." (2017, p. 46)

Perdigón (2017) sostiene que, en una entrevista, la Sra. Blanca le explicó que allí no se hacen limpias, sino que es un sitio dedicado a la Esperanza y a la conexión con Dios. Actualmente, Rosa lleva a cabo limpias, aunque no en el sitio. También la especialista comenta en su libro que, durante el período de su estudio, la afluencia al oratorio era de entre trescientas y quinientas personas diariamente. En las observaciones llevadas a cabo para la presente investigación no superan las tres decenas en días importantes como en las celebraciones de los rosarios. Tampoco la intención expresada a Perdigón de crear una asociación civil de la Santa Muerte para ayudar a niños con cáncer, síndrome inmune deficiencia adquirida (SIDA) o abandonados parece que ha podido materializarse. Todo lo cual indica un período de descenso en el fervor religioso comunitario, sumado a importantes cambios y adaptaciones de los sitios de devoción, como es indicado continuamente por los propios devotos quienes consideran que el culto está en crisis.

A la Muerte se le ofrendan velas, manzanas, a veces comida. Según Rosa es solo como símbolo, se le ofrece la comida para agradecer que intercedió ante Dios para que Él le concediera al creyente el sustento diario, no porque la Muerte lo coma o lo necesite. El agradecimiento por el alimento cotidiano es más comprensible justamente en un contexto donde no siempre es posible y, a veces, resulta un verdadero milagro; como expresa Ammerman (2014): no solo se lleva la religión a la cotidianidad, sino lo cotidiano a lo religioso. Es interesante que, como sostiene Perrée (2014) la relación con la Santa Muerte no está basada en la lógica del don- contradon, es decir, a una gracia otorgada se le devuelve un regalo. A la Muerte se le atiende como a un miembro más de la familia, se le cambia el agua, se le sustituyen las frutas y los vestidos, se le encienden veladoras, aunque no se le haya pedido nada, solo por el hecho de atenderla y que esté ahí. Claro que cuando se le pide algo y se siente el ruego contestado se llevan a cabo acciones de gracias especiales, pero incluso el resto del tiempo se continúa con las atenciones a la imagen de las cuales, por regla general, cada devoto tiene, al menos, una, frecuentemente más de tres.

A la Santa, explica Rosa, no se le hacen sacrificios cruentos, como se le hace a los orishas. La hermana Rosa también practica la santería de origen cubano, que como refiere Juárez Huet (2014), es probablemente la religión afroamericana más difundida en México. La devota a la Santa Muerte en su muñeca izquierda luce su "mano de Orula"3. Dice que

\footnotetext{
${ }^{3}$ Manilla de cuentas verdes y amarillas alternas, que denota que la persona recibió una protección particular de Orula, orisha de la adivinación, quien según se cuenta hizo un pacto con Ikú, la Muerte para que no tocara a aquellos a los que le hubiera dado su "mano". Las ceremonias donde se recibe son demasiado complejas para explicarlas aquí. Resulta paradójico a primera vista que una devota de la Muerte use un aditamento que en
}

Revista Cultura \& Religión Vol. XIII, 2019 Nº 2 (julio-diciembre)

Cómo citar este artículo: Garcés, R. (2019). "La Santa Muerte En La Ciudad De México: Devoción, Vida Cotidiana Y Espacio Público ”. Revista Cultura \& Religión.13(2). pp. 103-121. 
"entró en la santería para saber", pero no "se hizo santo", es decir no llegó al grado máximo de iniciación. Su padrino es cubano. Habla mucho sobre la mercantilización de la santería en México y de cómo se desacredita por convertirse en un negocio, donde exigen mucho dinero. Parece desilusionada con que su padrino trate mejor a "los que más tienen". En este caso Rosa combina elementos de santería con su creencia en la Santa Muerte a una manera de ganar en protección, asumiendo las partes que considera le son útiles, así como también hace prácticas shamánicas en "lugares de poder". Como plantea Pablo Semán: "La llamada múltiple afiliación religiosa no es una incoherencia o una simple astucia de los sujetos populares frente a la exigencia exclusivista: es el ejercicio de una compatibilización que organiza cosmovisiones y arreglos específicos de poderes sagrados.” (2001, p. 58)

\section{Viviendo con la Santa Muerte}

Rosa me presenta al hermano Diego quien se reconoce como chamán, curandero y clérigo ordenado de la Iglesia Católica Tradicional México- Estados Unidos. Lo acompaña su esposa, la hermana Hortensia. Su matrimonio fue bendecido en la Iglesia, "ante la Santa Muerte, imagínate la responsabilidad", dicen con sonrisa de orgullo. Lo primero que sorprende es que su discurso está muy elaborado para una persona que confiesa no haber superado la educación secundaria: explica que como parte del clero de la Iglesia Católica Tradicional debe estudiar para que los devotos, "los muerteños" los llama, ganen en claridad sobre la devoción a la Santa. Ambos se ganan la vida realizando rituales shamánicos, Diego, además, canta en los buses con su guitarra de caja rota para recoger dinero y su esposa vende ropa usada en puestos ambulantes, de manera no legal, a pesar de que por muchos años perteneció al cuerpo policial.

Según el hermano Diego el culto comenzó en el contexto urbano de manera subterránea alrededor de la década de los 50. Es aventurado decir, explica, que tiene raíces prehispánicas, aunque entre los aztecas existe la presencia de Mictlantecuhtli y Mictecacíhuatl, pero estas divinidades son una pareja, "una dualidad", afirma y "la Santa es una". Así, este creyente, shamán y por tanto familiarizado con lo indígena, apoya con sus propios argumentos la tesis de Perdigón (2017) quien considera que la Santa Muerte tiene un origen básicamente hispánico. Dice que existe una historia de que su primera aparición fue a un brujo de Catemaco, sin embargo, cuenta que en Zacatecas también se considera que es propia de ahí y surgió del culto de los mineros, quien por estar en riesgo constante le pedían por sus vidas, lo cual coincide con lo planteado por Gil Olmos (2012). Una vez más los creyentes apuntan hacia fuera de la Ciudad a la hora de buscar los orígenes del culto, esta vez a Veracruz y Zacatecas: resulta sintomático que ninguno sostenga que la devoción es chilanga, es decir, que comenzó en la Ciudad de México.

santería es utilizado para espantar precisamente a su objeto de devoción, pero completamente coherente con el sincretismo que autores como Renée de la Torre y Cristián Parker han descrito como propios de la religión popular latinoamericana.

\section{Revista Cultura \& Religión Vol. XIII, 2019 Nº 2 (julio-diciembre)}

Cómo citar este artículo: Garcés, R. (2019). "La Santa Muerte En La Ciudad De México: Devoción, Vida Cotidiana Y Espacio Público ”. Revista Cultura \& Religión.13(2). pp. 103-121. 
De lo que sí no tiene dudas es que la devoción es de origen popular, sin líderes visibles: los líderes se han hecho por voluntad propia, explica convencido. Esto hace que el culto sea muy variopinto, depende de cada persona. La relación que se establece con la Santa Muerte es muy personal: "es un miembro más de la familia, hasta nombre tiene", hecho señalado por investigaciones anteriores (Argyriadis, 2017; de la Fuente, 2015). Las ofrendas dependen del devoto y en cada estado asume las propias tradiciones locales, lo cual ha sido documentado (Yllescas, 2017). Diego la compara con las diferentes advocaciones de la Virgen quien asume la vestimenta y las celebraciones de cada lugar.

Sobre la iniciación en la devoción el hermano Diego y la hermana Hortensia afirman que la Santa Muerte escoge a los suyos, creencia que parece estar generalizada entre los creyentes (de la Fuente, 2015). De hecho, sostienen que esta investigación está inspirada por la Santa misma, para que la gente sepa la verdad sobre ella. Por eso dicen que tienen el deber de ayudar a realizarla. La manera en la que los creyentes se sienten llamados es subjetiva y según refieren, muy a menudo su acercamiento es gradual. Además, explican que los pone a prueba: parece que cada devoto tiene su propia ordalía en la que la Santa comprueba hasta dónde llega su fe. También refieren la posibilidad de que muera alguien cercano luego de comenzar a venerarla, pero insisten en que no es un trueque de vida por dones, sino una bendición o un acto de justicia: la persona que morirá, o ya era mejor que descansara, o tenía una fuerte deuda kármica, por ejemplo, un hermano de Hortensia murió a los nueve días de llevar a la Santa a su casa, me cuentan, pero ella dice con convicción: "ya estaba alcohólico, era mejor que descansara. Al final era una bendición."

El hermano Diego me cuenta que, de acuerdo con sus indagaciones, entre los primeros nombres conocidos de creyentes están la Sra. Blanca, Queta y hacia el quinquenio 19952000 comienzan sus oratorios a ser más famosos. Yllescas (2017) marca el año 2001 como el inicio del período de auge del culto. Por ese tiempo aparece David Romo Guillén, quien comienza la Iglesia Católica Tradicional. Según la pareja, la Santa escogió a México como el centro de su devoción porque los mexicanos establecen una relación con ella de camaradería, se ríen con ella y no le temen: "La Muerte ha escogido a México como su país, país de su raíz". Consideran que el culto está muy extendido: cuentan en millones sus devotos, aunque Diego reconoce que no hay un censo serio al respecto. Creen que los fieles se encuentran incluso entre el sacerdocio católico romano: - "... hay mucho pinche cura romano devoto de la Santa Muerte, en el closet", dice el hermano Diego con una mueca de burla. Algunos para disimular su culto, veneran a San Pascual Bailón, pero sobre todo la sincretizan con la Virgen de la Candelaria, la Virgen del Carmen, el Santo Niño de la Suerte y Nuestra Señora de los Desamparados ${ }^{4}$. En la Regla de Osha creen que sería Oyá, porque

\footnotetext{
${ }^{4}$ Muchos devotos, como señala Andrew Chesnut (2013) evitan exhibir sus imágenes de la Santa, debido a la relación que se ha establecido entre ella y el narcotráfico, así como por la condena de las Iglesias católica y protestantes. También hay cierta propensión a juzgar el culto como propio de las clases bajas, todo lo cual hace
}

Revista Cultura \& Religión Vol. XIII, 2019 № 2 (julio-diciembre)

Cómo citar este artículo: Garcés, R. (2019). "La Santa Muerte En La Ciudad De México: Devoción, Vida Cotidiana Y Espacio Público ”. Revista Cultura \& Religión.13(2). pp. 103-121. 
está en la puerta de los cementerios, aunque prefieren no mezclarlo con la santería pues "son dos asuntos distintos".

Los días de celebrar a la Santa son variados. La Iglesia Católica Tradicional la conmemora el 15 de agosto, otros el primero de cada mes, relacionado al culto con el de la Divina Providencia, algunos la celebran el día que la adquieren o la compran. Los más cercanos a la magia negra la festejan mensualmente cada día trece. Según Chesnut (2013), el carecer de una fecha particular para celebrarla la hace santa de todos los días, la disemina a lo largo del calendario y, se podría agregar, personaliza aún más su culto: el creyente celebra la adquisición de su imagen, alimentando así una relación personal y emocionalmente más cercana.

Sobre la práctica de las artes oscuras, Diego y Hortensia tienen muchas reservas: afirman que muchos creyentes afectan al culto con sus prácticas, aunque ellos mismos se autodenominan brujos. Consideran que la Muerte se cobrará las malas acciones: “...un mal devoto se quema en putiza, a algunos les da más cuerda porque propagan su culto, pero siempre terminan mal." De cualquier manera, es difícil que esas personas sean escuchadas por las fuerzas satánicas porque "el diablo es un príncipe y no se reúne con pendejos". Pero la Santa se lo tendrá en cuenta, creen, pues "tiene fama de justa y de pegadora" y "es muy dura con sus creyentes". La llaman "fiscal del karma". Esto es contradictorio a lo que señala Huffschmid (2012), que uno de los mayores atractivos del culto a la Santa es justamente su imparcialidad y su ausencia de juicio moral: aquí aparece no solo como jueza, sino como fiscal, acusadora del mal comportamiento de sus fieles. Sin embargo, resulta interesante que los creyentes no están interesados en un después escatológico: la devoción a la Santa y el tratar de venerarla o de comportarse bien no es para lo que pase post mortem, sino para un aquí y ahora muy pragmático; si tienen buena conducta es para ser recompensados en un plano material inmediato.

Por otra parte, “...estamos tratando de redimir nuestra fe", afirman. Me refieren que el culto está en crisis, a partir del escándalo del Padre David Romo Guillén, el fundador de la Iglesia Católica Tradicional y sus vínculos con "malos creyentes" y, además, antes de esto, de por sí la gente asociaba a "los muerteños" con narcos, ladrones y asesinos. Por eso tratan de mantener la mejor imagen posible para limpiar al culto de estas malas opiniones. Muestran sin reservas su fe de que la crisis actual es para que renazca mejor. "Para eso te trajo la Santa aquí,", dice mirándome a los ojos, haciéndome preguntarme sobre el papel legitimador que

que no siempre los creyentes muestren públicamente su fe o incluso recurran a imágenes que serían como un eufemismo visual de la Niña Blanca: según algunos entrevistados basta con una guadaña, una balanza, un reloj de arena y/o un búho para representarla y así mostrar su devoción solo a miradas avisadas y avezadas. No resulta extraño entonces que los altares públicos se encuentren en zonas pobres de la ciudad, o como dice Fragoso (2007), más vulnerables.

Revista Cultura \& Religión Vol. XIII, 2019 № 2 (julio-diciembre)

Cómo citar este artículo: Garcés, R. (2019). "La Santa Muerte En La Ciudad De México: Devoción, Vida Cotidiana Y Espacio Público ”. Revista Cultura \& Religión.13(2). pp. 103-121. 
puede tener el antropólogo y sobre qué esperan los colaboradores del trabajo que llevamos a cabo. Según el hermano Diego otro de los problemas del culto es que ha buscado legitimidad usando los rezos católicos (por ejemplo, el Padre Nuestro), mientras la Iglesia Romana los ha atacado constantemente, llamándolos satánicos.

Sin embargo, muestran su convicción completa de que "Dios primero". Mientras fuman me dicen convencidos: "Dios donde tiene que estar y los demás para abajo, que se avienten". "Ella es sierva de Dios", dice conmovida la hermana Hortensia. Al parecer, sobre esto hay un consenso total entre los líderes del culto en todo el país (Yllescas, 2017). Según el hermano Diego la Santa Muerte es una entidad angélica, relacionada con Abadón, Azrael y el Ángel Exterminador que se nombra en Apocalipsis 9.11 y en 1 Corintios 10.10. Es también el ángel que Moisés invocó a la salida de Egipto y el ángel que consoló a Jesús en el huerto del Monte de los Olivos. Según la hermana Hortensia el culto tiene un corpus que puede ser clasificado en tres partes: espiritual, ya que la Santa Muerte redime a las personas de sus malas conductas y las ayuda a elevarse: "saca a la gente del malvivir y rescata a los perdidos"; en segundo lugar una parte esotérica, que considera es la más buscada y la más tergiversada y finalmente, la parte mística, porque ella conecta a sus devotos con el Supremo: "muchos que andan por la calle no creen en Dios, pero creen en ella y ella los lleva a Él." Esta relación más cercana con la Santa Muerte que con Dios ha sido documentada en otras investigaciones (de la Fuente, 2015) y como señala Chesnut (2013), los creyentes no creen que su fe en la Santa sea opuesta a su catolicismo, sino complementaria. Este énfasis en el aspecto espiritual y místico del culto resulta coherente con lo que Possamai (2015) describe como democratización del misticismo, propio de la religiosidad actual.

Sobre su relación con la Santa Muerte en cuanto curanderos me cuentan que los rituales involucran yerbas, flores, frutas, pero no sangre y solo se hacen con intenciones curativas. Dicen que la Santa hace fumar mucho a sus creyentes (cigarros o porros). Según ellos, la Santa Muerte o la Divinísima, como también le dicen, no tiene nada que ver con "cosas negras", aunque "saca a un par de enemigos de en medio", pero no hay que pedírselo: "Ella sabe cómo". La labor del curandero no es solo sanar, sino también ayudar a bien morir, pero solo con rezos. Los curanderos no sanan el día de muertos, porque "quién les va a responder del otro lado si todo el mundo está en este."

La hermana Hortensia cuenta que como parte del cuerpo policial, al que perteneció durante años, siempre se sintió interesada por la Santa y sus altares donde estaba escrito: "No temas donde vayas porque morirás donde debes". Pero pasó mucho tiempo antes de que se convirtiera en devota:

Cuando va a mi hija al reclusorio, yo estaba mal con la Virgen de Guadalupe. ¿A quién le iba a pedir entonces? Le pedí a la Santita, le dije: -si Tú existes, sácame a la niña que Tú sabes que no es mala, fue por estar en un lugar equivocado y con gente equivocada. A los nueve días exactos salió. Yo le había prometido que si me lo cumplía le hacía un altar. Pasó el tiempo y no lo hice. Un día vi a un tipo

Revista Cultura \& Religión Vol. XIII, 2019 № 2 (julio-diciembre)

Cómo citar este artículo: Garcés, R. (2019). "La Santa Muerte En La Ciudad De México: Devoción, Vida Cotidiana Y Espacio Público ”. Revista Cultura \& Religión.13(2). pp. 103-121. 
en la calle que vendía una y dije: -chin, ya tengo que hacer el altar. Solo llevaba 100 pesos. Cuando le pregunté en cuánto la vendía me dijo: -En 100 pesos, te la dejo. Es que le faltaban las manitos. La llevé a la casa y cuando entré, mi hermano se persignó, asustado. A los nueve días exactos se murió. Tuve muchos problemas por eso en mi familia, luego vimos que todo lo que consideramos malo, después era una cosa buena. Ya tengo con ella 12 años. (Entrevista a la hermana Hortensia, 6 de diciembre de 2018)

En este caso la veneración a la Santa es un culto familiar devenido comunitario, sin jerarquización clara, que ratifica su origen fuera del marco delictivo, como ya había cuestionado Fragoso (2007), pero también parece haber venido de fuera de la ciudad. El hecho de conducir el rosario no parece dar un status superior a la Hna. Rosa, quien muestra una marcada deferencia por otros adoradores, como el hermano Diego, sin embargo, es notable que la Sra. Blanca ocupa una posición distinta, en tanto dueña del oratorio, aunque resulta distante incluso del resto de los fieles que asisten y no dirige el rosario. Las relaciones que se establecen entre los creyentes no parecen organizadas y ni existe un liderazgo incuestionado. Como plantea Huffschmid:

Es un rito que diluye las fronteras entre lo privado y lo público, lo individual y lo colectivo. Requiere de la convicción íntima del devoto, cada uno teje sin intermediarios su propio lazo con la Santa Muerte, a pesar del estigma social; pero son también constitutivas su escenificación pública y la formación de una precaria unidad de creyentes, sin llegar a ser, en ningún momento, una comunidad estable o cerrada. Prescinde de cualquier institucionalización, no es ni secta ni iglesia. Sería acaso justamente su carácter amorfo y poco calculable el mayor desafío para su principal competidor, la iglesia católica. (2012, p. 102)

\section{La lucha por el espacio}

Una inflexión importante en el culto a la Santa Muerte fue la guerra al narcotráfico declarada por el presidente Felipe Calderón, a partir de su toma de posesión a finales de 2006. Esta guerra contra el narco implicó además de un alza inusitada de la violencia, la destrucción de altares dedicados a la Niña Blanca, a lo largo de toda la nación mexicana, como una lucha feroz por el espacio que atacaba, en este caso, a narcos y a simples creyentes por igual. Fue una manera violenta de condenar al otro a la invisibilidad, de negarle lo que podríamos llamar con Heidegger el Dasein, es decir, su "ser/estar- ahí". Es un intento de borrar cierta "escritura de la ciudad", como la denomina Lefebvre (1973) y con esto de eliminar la huella del otro que habita este espacio "craterizado", como diría el filósofo francés (Lefebvre, 1973), de desterrar a un otro con el que no se quiere cohabitar.

En la primera visita realizada a la casa del hermano Diego y la hermana Hortensia, sita en la colonia 15 de agosto de la alcaldía Gustavo A. Madero, limítrofe con el Estado de México, me muestran con dolor los restos de un altar que habían comenzado a construir frente a su puerta y que se lo derribaron, "por suerte no habíamos puesto las imágenes todavía". La solución que encontraron para esto fue la de pintar toda la puerta de la entrada con la imagen de la Santa y colgar una gran lámpara roja con forma de Muerte encapuchada. Así se hacen

Revista Cultura \& Religión Vol. XIII, 2019 № 2 (julio-diciembre)

Cómo citar este artículo: Garcés, R. (2019). "La Santa Muerte En La Ciudad De México: Devoción, Vida Cotidiana Y Espacio Público ”. Revista Cultura \& Religión.13(2). pp. 103-121. 
notar entre vecinos que según describen "son muy mochos" y en un lugar muy cercano a la Villa de Guadalupe. El altar en la calle es un modo de habitar la ciudad, de apropiarse del espacio público, de decir "estoy aquí y quiero que sepas que estoy". La Santa Muerte se convierte en uno de los modos de anclaje a la ciudad y de manifestar su pertenencia a ese conglomerado urbano, al tráfago citadino de otro modo, para ellos, impersonal. No obstante, esta lucha por el espacio no es un intento de sacralización de este, en este caso desaparece la conocida distinción dual (sagrado- profano) de la espacialización, como plantea Flores (2016) sobre algunos territorios argentinos. Como sostiene Pablo Semán la religión popular, en general, es cosmológica en tanto "está más acá de las distinciones entre lo trascendente y lo inmanente, entre lo natural y lo sobrenatural, y supone que lo sagrado es un nivel más de la realidad." (2011, p. 54)

La destrucción de altares públicos lleva a una pregunta planteada por Lefebvre (2013): ¿qué tipo de espacio social se quiere producir? ¿Para quién? "Efecto de acciones pasadas, el espacio social permite que tengan lugar determinadas acciones, sugiere unas y prohíbe otras", dice el filósofo francés (Lefebvre, 2013 p.129). ¿Qué acciones se quiere sugerir o prohibir con la negación de la veneración pública de la Santa Muerte, más allá del culto mismo? La relación Santa Muerte y narcotráfico ha sido en gran medida creada y reforzada por los medios y el ataque a la imagen no es un daño directo a la delincuencia, así que la destrucción o relegación de sus manifestaciones públicas se convierte, quizás en una manera de blanquear el espacio social, de impedir que se trasvase o se yuxtaponga al espacio que se quiere para mantener cierta imagen, pero no se trata de resolver el problema real del tráfico de drogas o de la violencia.

Los altares quedan entonces, en el espacio que el habitante deseado, clase media "fresa", no los puede ver, ni se los encuentra nunca y si no se les ve, no existen. Muchos de estos lugares suelen ser territorio vetado para el resto de los habitantes de la ciudad, especialmente luego de la puesta del sol, por estar asociados con la delincuencia. A cualquier extranjero, a su llegada a la ciudad se le recomienda evitarlos a toda costa. Es esta la dimensión simbólica de la segregación urbana de la que habla Saraví (2008) y como sostiene este autor, la base principal de estos estigmas territoriales es la inseguridad (Saraví 2008) que las transforma en zonas prohibidas:

Las zonas prohibidas no son sino el reverso del aislamiento social. Distintos sectores sociales reconocen sus propias zonas prohibidas, y esto repercute no sólo en sus respectivas prácticas, sino mucho más importante aún, sus consecuencias se perciben en la estructura social misma: la presencia y encuentros se reducen, la interacción disminuye, el desconocimiento mutuo crece, y los prejuicios y estigmas se constituyen en el principal mecanismo de aproximación al otro. (Saraví, 2008, p. 107)

Estas zonas son espacios estigmatizados, segregados debido a la relación directa establecida entre pobreza, marginación y criminalidad; la Santa, con idénticas asociaciones también sufre la misma segregación. Es en la ciudad no visible, no mostrada, donde la Santa

Revista Cultura \& Religión Vol. XIII, 2019 № 2 (julio-diciembre)

Cómo citar este artículo: Garcés, R. (2019). "La Santa Muerte En La Ciudad De México: Devoción, Vida Cotidiana Y Espacio Público ”. Revista Cultura \& Religión.13(2). pp. 103-121. 
Muerte se exhibe en la vía pública: parece que, en las colonias más chic, la Santa es relegada al espacio íntimo. No obstante, esto no significa que sea el espacio exclusivo de su culto, que se extiende a todas partes, sin distinción de clases, status, ocupación u origen, en un verdadero proceso de gentrificación, como diría Possamai (2015). Al fin y al cabo, uno de los mayores atractivos de esta devoción es la vivencia personal de la fe en la Niña Blanca, de la cual, dicen sus creyentes con orgullo convencido: "Ella no discrimina."

\section{Conclusiones}

El desarrollo de una investigación etnográfica que tome lo urbano, lo cotidiano y lo religioso como ejes de reflexión resulta muy incipiente aún. Es de esperar en el futuro un mayor número de cientistas sociales que se dediquen a estos temas, que son un terreno muy fértil para la comprensión de nuestros habitares en la multiplicidad de ciudades que coexisten en la misma geografía. En lugares de alta vulnerabilidad social, es evidente que muchas de las personas están muy cerca de la muerte, literalmente. La precariedad de sus formas de ganarse la vida, los altos grados de delincuencia, la carencia de seguro médico hace que la muerte sea una presencia constante en su vida, "la única cierta" como suelen decir. De ahí que las peticiones más comunes a la Santa Muerte sean por prosperidad económica, salud, protección ante la violencia, es decir aquellas necesidades cotidianas más apremiantes que no tienen cubiertas. La devoción a la Santa Muerte se convierte en una afirmación de la vida en un contexto de riesgo.

Este culto calidoscópico se ancla en tradiciones propias del catolicismo popular, siendo así reinterpretado y practicado en un marco básicamente cristiano, lo cual es evidenciado en el uso de rosarios, padrenuestros, escapularios, novenas, promesas, del símbolo de la cruz, del acto de persignarse e incluso en el respeto al dogma trinitario. Esta devoción genera un espacio colectivo con una jerarquización difusa, donde hay momentos de prácticas comunitarias de una fe que es vivida de manera profundamente individual, de acuerdo con la(s) tradición(es) en las que se inscriba cada practicante (como en este caso, la santería y/o el neoshamanismo).

Resulta imprescindible destacar que estas conclusiones no pueden extenderse a otras ciudades del múltiple territorio mexicano sin un análisis particular previo. Como dicen los propios creyentes, la Santa asume características propias de cada estado en el que es venerada. Los fieles entrevistados asumen a la Santa como inmigrante en la ciudad, originaria de Oaxaca, de Zacatecas o de Veracruz, donde quizás la población que practica el culto sea diferente. Es muy probable que esta devoción haya llegado a la ciudad luego del boom demográfico provocado por la migración, acaecido en la mitad del siglo XX.

En la Ciudad de México es evidente que los altares públicos cumplen una importante función y son muy frecuentes los dedicados a la Virgen de Guadalupe. Sin embargo, los

Revista Cultura \& Religión Vol. XIII, 2019 Nº 2 (julio-diciembre)

Cómo citar este artículo: Garcés, R. (2019). "La Santa Muerte En La Ciudad De México: Devoción, Vida Cotidiana Y Espacio Público ”. Revista Cultura \& Religión.13(2). pp. 103-121. 
altares a la Niña Blanca están circunscritos a zonas precarias, lo cual brinda una idea sobre la concepción clasista que permea esta devoción en esta megalópolis. El derrumbe de muchos de estos altares implica la negación a otro, considerado un habitante indeseable por pobre, por "naco" y, por ende, posible delincuente, constituyendo un proceso de blanqueamiento del espacio público. Los altares públicos a la Santa Muerte, luego del comienzo de la guerra al narco se convirtieron en un problema sociopolítico, en una lucha por el espacio y la visibilidad. Que se mantengan, a pesar de la campaña contraria que han realizado las iglesias cristianas, la prensa y el propio gobierno significa que cuenta con bases firmes, aunque la cantidad de fieles que acuden a los espacios más formalizados parece que ha descendido en la segunda década de este siglo. Resulta una situación sumamente interesante poder ser testigo de los vaivenes de un culto tan fluido, que, sin dudas, aún dará mucho material para investigaciones futuras.

\section{Referencias}

Ammerman, N. (2014) "Finding Religion in Everyday Life." Sociology of Religion, 75(2), pp.189-207 visitado el 2 de mayo de 2019 (DOI:10.1093/socrel/sru013)

Argyriadis, K. (2017) "Panorámica de la devoción a la Santa Muerte en México: pistas de reflexión para el estudio de una figura polifacética." La Santa Muerte: espacios, cultos y devociones. (pp. 33 -64) Hernández Hernández, A. (compilador) Tijuana: El Colegio de la Frontera Norte; San Luis Potosí: El Colegio de San Luis.

Chesnut, A. (2013) Santa Muerte. La segadora segura. México: Ariel

Cruz Rodríguez, M. S. (2000) "Periferia y suelo urbano en la Zona Metropolitana de la Ciudad de México.” Sociológica, 15(42), pp. 59-90

De la Fuente Hernández, S. G. (2015) "La Santa Muerte en la vida cotidiana de una familia de la colonia Ajusco." Vita Brevis. Revista electrónica de estudios de la muerte. 4(6), pp. 67- 78 Visitado el 8 de mayo de 2019 (https://mediateca.inah.gob.mx/repositorio/islandora/object/articulo:14796)

De la Torre, R. (2012). "La religiosidad popular como "entre-medio" entre la religión institucional y la espiritualidad individualizada." Civitas. Revista de Ciências Sociais, 1(3), pp. 506-521

Díaz, I. (2016). "Política urbana y cambios sociodemográficos en el centro urbano de Ciudad de México ¿gentrificación o repoblación?” Territorios, 35, pp. 127-148. Visitado el 4 de mayo de 2019 (DOI: dx.doi.org/10.12804/territ35.2016.06)

Flores, F. C. (2016) "Espacialidad y religiosidad: encuentros y desencuentros teóricometodológicos." Revista Cultura y Religión, 10(1), pp. 3-16

Fragoso Lugo, P. O. (2007) "La muerte santificada: el culto a la Santa Muerte en la Ciudad de México." Revista de El Colegio de San Luis, 9(26-27), pp. 9- 38

Gaytán Alcalá, F. (2008) "Santa entre los malditos. Culto a la Santa Muerte en el México del siglo XXI.” LiminaR. Estudios sociales y humanísticos, 6(1), pp. 40- 51

Revista Cultura \& Religión Vol. XIII, 2019 Nº 2 (julio-diciembre)

Cómo citar este artículo: Garcés, R. (2019). "La Santa Muerte En La Ciudad De México: Devoción, Vida Cotidiana Y Espacio Público ”. Revista Cultura \& Religión.13(2). pp. 103-121. 
Gil Olmos, J. (2012) La Santa Muerte: virgen de los olvidados. México: Penguin Random House Grupo Editorial México.

Gracia Sain, M. A. (2004) "El poblamiento de la Zona Metropolitana de la Ciudad de México: análisis y empleo de una tipología explicativa." Perfiles Latinoamericanos, 2, pp. 107- 142

Hernández Hernández, A. (2017) "Quince años de convivencia con la Flaquita. Memorias de un hojalatero social.” La Santa Muerte: espacios, cultos y devociones. (pp. 193- 206) Hernández Hernández, A. (compilador) Tijuana: El Colegio de la Frontera Norte; San Luis Potosí: El Colegio de San Luis.

Huffschmid, A. (2012) "Devoción satanizada: la Muerte como nuevo culto callejero en la Ciudad de México.” iMex. México Interdisciplinario. Interdisciplinary Mexico, 2(3), pp. $97-107$

Ingold, T. (1993) “The Temporality of the Landscape.” World Archaeology, 25(2), pp. 152174

Ingold, T. (2005) "Epilogue: Towards a Politics of Dwelling." Conservation and Society, 3(2), pp. 501-508

Juárez Huet, N. (2014) "Religiones afroamericanas en México: hallazgos de una empresa etnográfica en construcción.” Revista Cultura y Religión, 8(1), pp. 219-241

Lefebvre, H. (1973) El derecho a la ciudad. Barcelona: Ediciones Península

Lefebvre, H. (2013) La producción del espacio. Madrid: Capitán Swing

Perdigón Castañeda, K. (2017) La Santa Muerte, protectora de los hombres. México: Secretaría de Cultura. Instituto Nacional de Antropología e Historia.

Parker, C. (1993) Otra lógica en América Latina. Religión popular y modernización capitalista. México- Santiago: Fondo de Cultura Económica.

Perrée, C. (2014) "Mexico, de San Judas à la Santa Muerte. Logiques votives et rituels transversaux en milieu urbain." L'Homme. Revue française d'anthropologie. 211. Visitado el 28 de abril de 2019 (DOI:10.4000/lhomme.23587)

Possamai A. (2015). "Popular and lived religions." Current Sociology Review, 63(6), pp. 781-799

Saraví, G. A. (2008) "Mundos aislados: segregación urbana y desigualdad en la ciudad de México." Revista Eure, 34(103), pp. 93-110

Semán, P. (2011). "Cosmológica, holista y relacional: una corriente de la religiosidad popular contemporánea.” Ciencias Sociales y Religión/ Ciências Sociais e Religião, 3(3), p. 45-74

Yllescas Illescas, J. A. (2017) "La Santa Muerte, ¿un culto en consolidación?” La Santa Muerte: espacios, cultos y devociones. (pp. 65- 84) Hernández Hernández, A. (compilador) Tijuana: El Colegio de la Frontera Norte; San Luis Potosí: El Colegio de San Luis.

Revista Cultura \& Religión Vol. XIII, 2019 N² 2 (julio-diciembre)

Cómo citar este artículo: Garcés, R. (2019). "La Santa Muerte En La Ciudad De México: Devoción, Vida Cotidiana Y Espacio Público ”. Revista Cultura \& Religión.13(2). pp. 103-121. 